\title{
合流分岐部を通る流動形態と壁せん断応力*
}

\author{
山口隆平*1, 岡部洋*2, 野川順一*3 \\ 氏家 弘*4, 高 倉 公 朋*4
}

\section{Flow Structure and Wall Shear Stress through Confluent and Bifurcating Channel}

\author{
Ryuhei YAMAGUCHI, Hiroshi OKABE, Jun-ichi NOGAWA. \\ Hiroshi UJIIE and Kintomo TAKAKURA
}

\begin{abstract}
Cerebral artery aneurysms often form in the circle of Willis, most frequently in the asterior communication artery. This artery forms a junction between two confluent arteries and two bifurcating arteries. In the present study, the flow field around the anterior communicating artery is simulated by two confluent tubes, two bifurcating tubes, and junctional region connecting to four tabes. The wall shear stress and the velocity profile around the anterior communicating artery in laminar steady flow were experimentally studied using an electrochemical method and a laser Doppler velocimeter, respectively. The flow around the junction is found to be very unstable and the wall shear stress to vary greatly around the apex.
\end{abstract}

Key Words: Bifurcation, Confluence, Velocity Profile, Wall Shear Stress, Cerebral Artery, Aneurysm, Biomechanics

\section{1. 暳}

生体内の血管は各種の分岐および合流部で構成され ている．血管の病理学的異変がこれらの部位に多発す ることが知られ，血管の幾何学的形状に起因寸る血行 力学的因子が関与するとされている．血管の幾何学的 形状に起因する病理学的異変は, 主として動脈硬化性 病変と血管破裂に至る動脈りゅうの二つに大別され， その血行力学的発生には相反する因子が関与するとさ れている(1) - (5). 病理学的には, 動脈硬化性病変は流れ が主管から枝管へ分岐していく中枢壁(流れ分割点に 相対するはく離流の発生が予測される枝管壁)上に観 察され ${ }^{(5) \sim(9)}$, 壁せん断応力の小さな部位ではせん断速 度に依存する物質伝達の低下と動脈硬化症との関連が 指摘されている。他方，人体の脳内ウイリス輪 (図 1) は, クモ膜下出血を生じる脳底部に位置する このウイリス輪の一部を構成する前交通動脈は, 左右

* 原稿受村 1995 年 5 月 9 H

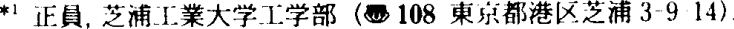

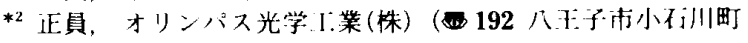
2951).

*3 学生貝, 芝浦工業大学大学院

*4 東京好子医科大学脳神経センター－162 東京都新缩区河田 町 8.1).
の前大脳動脈を連結する動脈で，どちらか一方の血流 供給が低下した場合に側副血行路として働く．幾何学 的には，左右の対向する二つの合流流机が合流(連結) 直後に合流管にほほ直角な同一 2 方向の流れに分岐す るという特異な部位であり，ウイリス輪のうちでも動 脈りゅうの最多発部位である。動脈りゅうはこの合流 流れが分岐する流れ分割点 (Apex) 近傍に発生しやす く，動脈硬化症に対する血行力学的要因とは反対に流 れが衝突し垂直およびせん断応力の大きな部位との関 連が指摘されている(10)(11)。

前交通動脈では合流流れが合流直後にほほ直角な同 一 2 方向の流机に分岐するという幾何学的特徵のた め，流体力学的には前交通動脈回りの流れは極めて不 安定であり，流れの急変が予測される，病理学的には， 前交通動脈の上流の両前大脳動脈の幾何学的非対称性 や両動脈压の不均衡と動脈りゅう発生頻度が、森竹・ 大柣 ${ }^{(10 \times(11)}$, Andrews -Spiegel ${ }^{(12)} や$ Kayembe $ら^{(13)}$ に より検討されている.血行力学的には, Roach ら(2), 森 竹・大柣(10)(11)やUjiie ら ${ }^{(14)}$ が流れの可視化などによ り流動形態から流れが衝突する部位と動脈りゅう発生 との関連を指摘している。しかしながら，前述のよう に前交通動脈の幾何学的形状の特異性や流れの不安定 などのため, 合流直後に分畦する前交通動脈回りの流 
れ構造や血管壁に直に作佣する壁せん断心才は調査さ れていない。

本研究では，脳内の動脈りゅう発生の $30 \%$ 以上の最 多発部位 ${ }^{(10)(12)}$ である前交通動脈回りの流れ構造およ び血管壁に直に作用する壁せん断応力を実験的に検討 する。実験では前交通動脈回りの基本的流れを検討す るため，対向する二つの合流流れが合流後に直角な间 一2方向の流机に行岐する合流・分岐流路でモデル化 する。速度分布をレーザドップラー流速計(以後 LVD と呼ぶ）により計測し，壁せん断统力を酸化還元系の 電解液を用いた電気化学的手法(16)(17)により測定す る。その結果，合流分岐点近傍の流九構造と動脈りゅ う発生部位との関係を検討する。

\section{おもな記号}

\section{$D_{0} ：$ 合流管内径 \\ $D_{1}$ : 枝管内径}

$Q_{L}, Q_{R}:$ 左・右合流管内の流量

$Q_{S}$ : 分岐後の両枝管内の流量

$R_{C}:$ 流九分割点曲率半径

$R e$ :レイノルズ数 $=U D_{0} / \nu$

$R_{S}:$ 枝管八の側壁曲率半径

$U$ : 左・㕲合流管内の平均流量に基の゙く平均速度

$u: x$ 方向速度成分

$v: y$ 方向の速度成分

$x$ : 合流管軸

$y$ : 枝管軸

$z$ : 主・枝管で中間面に垂直軸

$\delta$ ：前交通動脈内径

$\nu$ : 作動流体の動粘度

$\rho:$ 作動流体の密度

$\tau, \tau_{k}, \tau_{5}$ ：左・有合流管上流，枝管下流でのポアズイュ 流れの壁せん断忍力

$\tau_{w}$ : 左・有合流管内0平均流量に基の゙くポアズイ 工流れの壁せん断伈力を 2 として無次元化し た壁せん断応力 $=\tau_{W}^{*} D_{0} /(4 \rho \nu U)$

$\tau *$ : 有次元壁せん断応力

\section{2. 供試流路モデル，測定断面 および実験方法}

$2 \cdot 1$ 合流・分岐流路 (前交通勤脈)モテル 前交通 動脈の幾何学的特徵は（図 1)，合流管である上流側の 二:つの前大脳動脈が合流すると同時に，合流管軸にほ 浪直角な同一方向の二つの下流側前大脸動脈に分岐 し，合流部を前交通動脈が連絡するという基本形状で 示される．前交通動脈可りの合流から行岐に至る流机

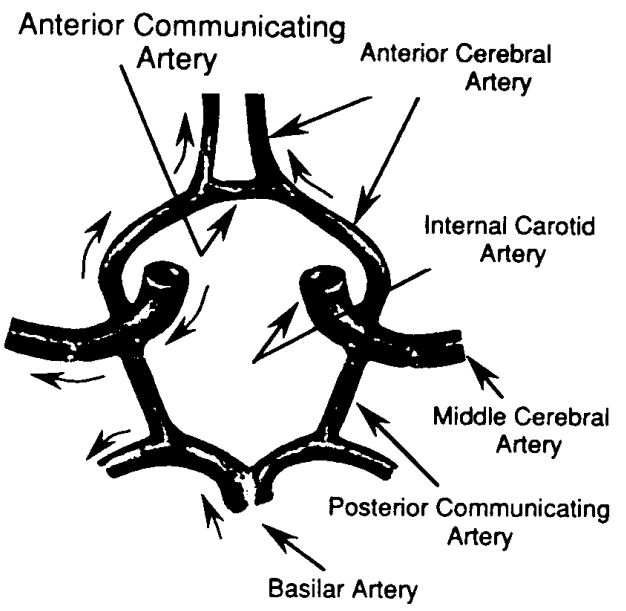

Fig. 1 Sketch of circle of Willis

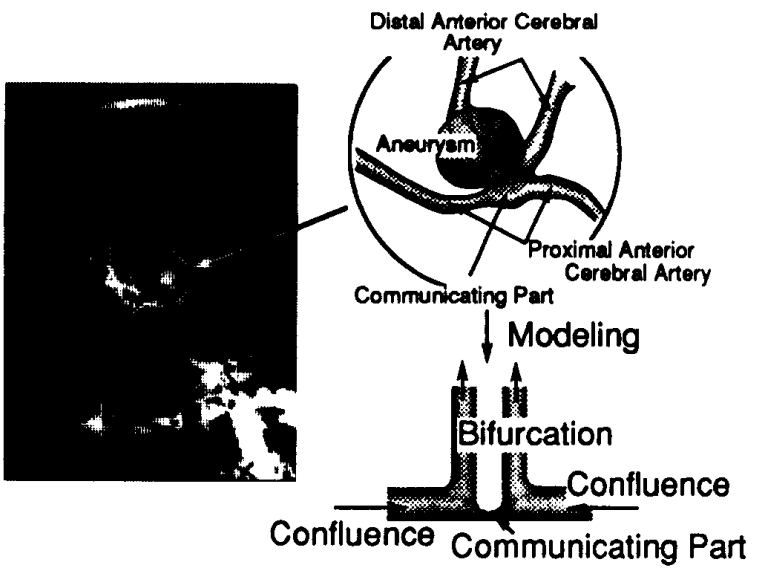

Fig. 2 X-ray with aneurysm, sketch of communicating part and modeling

分割点近傍に動脈りゅうを持つ X 線写真の症例と。 前交通動脈の合流・分岐流路のモデル化を図 2 に示す. 実際の上流側の二つの前大脳動脈は $180^{\circ}$ て対向する 合流管というよりも，より小さな角度(例えば，120程 度)で合流している。しかしながら，180で対向する合 流管をもつ本モデルは, 前交通動脈の基本的な幾何学 的特徴を示している。

モデル化した前交通動脈近傍の供試流路形状を図 3 に示す. 合流管直径 $D_{0}=24 \mathrm{~mm}$, 枝管直径 $D_{1}=18$ $\mathrm{mm}$, 前交通動脈径 $\delta=D_{0} / 4=6 \mathrm{~mm}$, 流九分割点曲率 半径 $R_{C}=D_{1} / 2=9 \mathrm{~mm}$, 側壁曲率半径 $R_{S}=D_{1} / 2=9$ $\mathrm{mm}$ とする，供試流路は厚さ $30 \mathrm{~mm}$ の 2 枚のアクリ ル板を重权合わせ，河アクリル板に合流管，枝管およ び前交通動脈をそれぞれ対応する直径のボールエンド ミルで機械加工し，それぞれの接続面が滑らかな曲面 壁で接続されるように研磨してある。坐標は合流管外 壁の中央部 $\mathrm{A}_{20}$ に原点 $\mathrm{O}$ をおき，流れ分割点を $\mathrm{B}_{0}$ ，合 流管，枝管軸をそれぞれ $x, y$ 軸とする，速度成分は， 


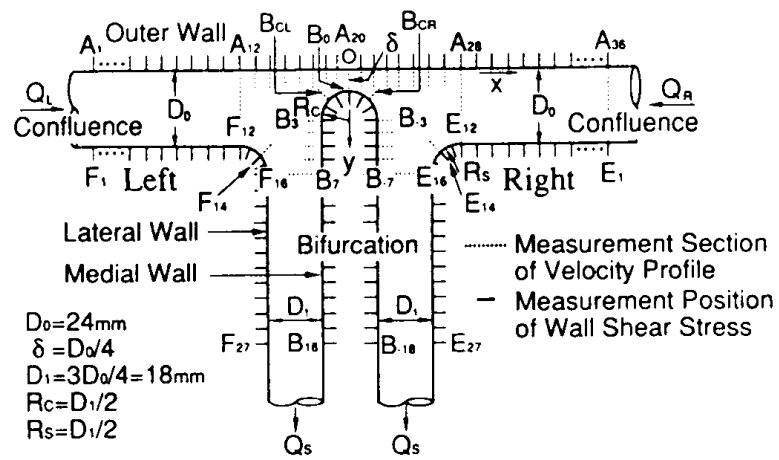

Fig. 3 Sketch of flow field. measurement location in confluenet and bifurcating channel

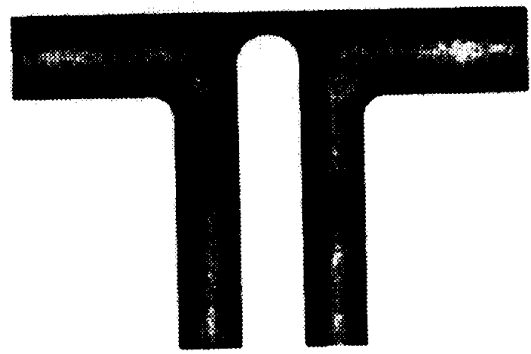

Fig. 4 Cast of confluent and bifurcating channel

$x ， y$ 方向の速度をそれぞれ $u ， v$ とする，供試流路モ デルに石费を注入して得られた供試流路外形を図 4 に 示寸.

対称面にある管壁のうち，合流管に浻う外壁 $\left(\mathrm{A}_{i}\right)$ ， 合流管から枝管に至る側壁 $\left(\mathrm{E}_{i}, \mathrm{~F}_{i}\right)$ および中間壁 $\left(\mathrm{B}_{i}\right.$, $\left.\mathrm{B}_{-i}\right)$ とする。これらの位置 $\left(\mathrm{A}_{i}, \mathrm{~B}_{i}, \mathrm{~B}_{-i}, \mathrm{E}_{i}\right.$ および $\left.\mathrm{F}_{i}\right)$ は壁せん断㐫力測定用の電極位置を示し，流れ分割点 近傍では $4 \mathrm{~mm}$, 流れ分割点から離れた位置では 5 $\mathrm{mm}$ ごとに埋め込んである。

速度分布の測定断面を図 3 に破線で示す．測定断面 は流れ分割点 $\mathrm{B}_{0}$ から十分離れた右合流管上流 $\mathrm{A}_{36}-\mathrm{E}_{1}$, 合流管から曲面壁への移行部 $\mathrm{A}_{28}-\mathrm{E}_{12}, \mathrm{~A}_{12}-\mathrm{F}_{12}$, 曲面 壁から枝管への移行部 $B_{-7}-E_{16}, B_{7}-F_{16}$ おび流れの 変化が大きいことが期待される流れ分割点回りなどて ある。

$2 \cdot 2$ 速度分布測定と壁せん断応力の算出速度 分布を $4 \mathrm{~W}$ アルゴンレーザを光源とした後方散乱形 の LDVにより測定する、レーザ光は流路对称面に垂 直に入射する。速度分布の測定は流路対称面上で 1 $\mathrm{mm}$ ごとに, 壁上の壁せん断応力を算出するために管 壁から $1 \mathrm{~mm}$ までの範囲を $0.2 \mathrm{~mm}$ 間隔で測定する. このうち管壁と管壁から $0.6 \mathrm{~mm}$ までの 3 点の接線 方向速度から速度こう配を求め, 壁せん断応力を算出 する。

作動流体として，チオシアン酸カリウム $\mathrm{KSCN}$ の
飽和水溶液を用いる。一般に，流路材であるアクリル の届折率 $n=1.490$ と使用流体の届折率は異なる. $\mathrm{KSCN}$ の飽和水溶液(質量混合比 水: $\mathrm{KSCN}=1$ : 2.27)の届折率はアクリルの届折率にほほ等しく，こ の飽和水溶液を用いることにより流路材と流体との間 の届折の影響を除去できる. 液温 $22^{\circ} \mathrm{C}$ 場合, 密度 $\rho$ $=1.44 \mathrm{~g} / \mathrm{cm}^{3}$, 動粘度 $\nu=2.18 \times 10^{-6} \mathrm{~m}^{2} / \mathrm{s}$ おび届折 率 $n=1.490$ である.これら物性の測定は, 密度を比重 計, 動粘度をオストワルド粘度計, 届折率をアタゴ社 製の屈折率計(R-5000)で測定した。

$2 \cdot 3$ 壁せん断応力の測定壁せん断忍力の測定 方法は前報同様であり，等モル濃度 $10^{-2} \mathrm{M}$ の黄血塩， 赤血塩および支持電解質として $1 \mathrm{M}$ の水酸化カりウ ムからなる混合電解液を用い，試験電極と対極との間 に流れる電流の三乗が壁せん断応力でに比例すると ころの電気化学的方法により測定する ${ }^{(16)(17)}$.このとき 使用した作動流体の動粘度 レおよび密度 $\rho$ は純水よ り若干大きい程度で, 液温 $30^{\circ} \mathrm{C}$ の場合それそれれ= $0.836 \times 10^{-6} \mathrm{~m}^{2} / \mathrm{s}, \rho=1.04 \mathrm{~g} / \mathrm{cm}^{3}$ である.

2・4 流れの可視化 両管軸を含む対称面に外壁 (A) 側よりレーザシート光を入射することにより，対 称面の流れを可視化した。密度 $1.04 \mathrm{~g} / \mathrm{cm}^{3}$, 直径 100 $\mu \mathrm{m}$ のポリスチレン粒子を散乱粒子とし，作動流体は 散乱粒一·と同程度の密度をもつチオシアン酸カリウム の水溶液（質量比 水： $\mathrm{KSCN}=1: 0.16$ )を用いた。

\section{3. 実験結果および考察}

一般に血管は弾性管であり，血液は体積の40\%を有 形成分が占める非二ュートン流体であるが，本研究で は剛体管を通るニュートン流体により検討する。

他方，実験では合流流量比として正常な状態と考え られる等流量比 $\left(Q_{R} / Q_{L}=1.0\right)$ と一方の流量 $Q_{L}$ が何ら かの)理由で減少した不均衡流量比 $\left(Q_{R} / Q_{L}=1.5\right)$ を対 象とする.分岐後の左側と右側の枝管を等しい流量 $Q$ s が流れるように設定する，一般に，血管は未梢の組織 が必要とする流量を供給する。したがって，何らかの 障害で上流側の合流流量比が変化したとしても，分岐 後の枝管を通る流量 $Q_{S}$ は末梢の組織を維持するうえ でつねに等しく保たれると考えることができる(10). 闭 合流管の平均流量 $\left(Q_{R}+Q_{t}\right) / 2$ に基づく合流管での平 均レイノルズ数を 400 とする。

$3 \cdot 1$ 流れの可視化と管軸方向速度分布 レイ， ルズ数 $R e=400,2$ 種類の流量比 $Q_{R} / Q_{L}=1.0$ および 1.5 の場含、対称面上の流れの可視化を四 5(a)およ び瓦5(b)に示す。これら可視化からスケッチした流 れと対称面上の管軸方向速度分布を，それぞれ図 


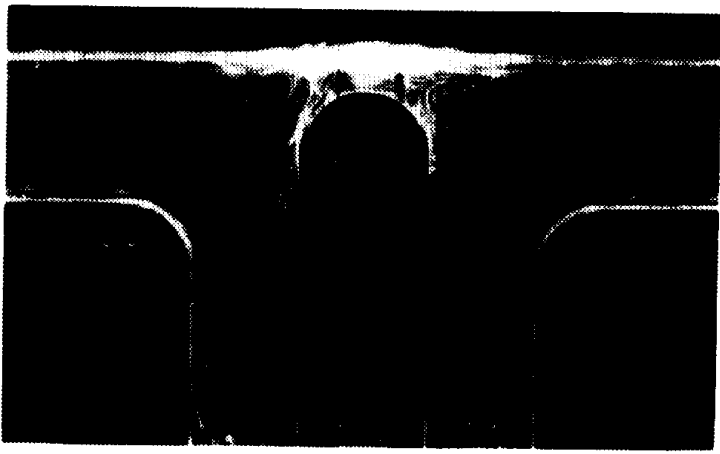

(a) Even flow ratio $\left(\operatorname{Re}=400, Q_{R} / Q_{L}=1.0\right)$

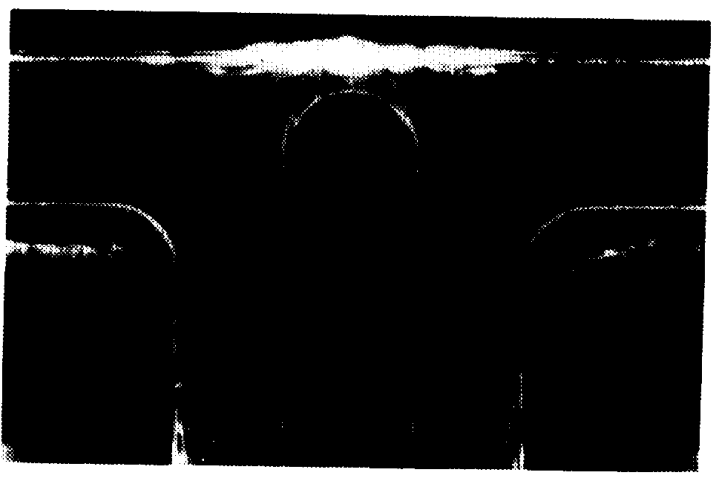

(b) Imbalance flow ratio $\left(R e=390, Q_{R} / Q_{L}=1.5\right)$

Fig. 5 Flow visualization at symmetrical plane

6(a)およ゙戍 6(b) に示す. 図 6 の代表速度のスケー ルは，左右合流管の平均流量に基づく半均速度 $U$ を 示し、 $S$ はよどみ点を表す。

なお、レーザシート光は $1.5 \mathrm{~mm}$ ないし $2 \mathrm{~mm}$ 程度 の厚みをもつため，図 5 には対称面上の流れに加え， 対称面の上下に発生する二次の旋回流による対称面を 横切り交差する流線が含まれる，図6では、これら交 差する流線を削除してある。

等流量比 $Q_{R} / Q_{l}=1.0$ の場合 $[$ 図 $6(\mathrm{a})]$ ，速度分布 はほほ左右対称となっている。流れ分割点に近づと 右外壁上 $\mathrm{A}_{26}-\mathrm{A}_{22}$ でははく離流が発生し，左有の外壁 に治って一対の対称な渦が発生する，中間壁では，左 右の合流管からの流れが衝突する $\mathrm{B}_{3}-\mathrm{B}_{4}$, および $\mathrm{B}_{-3}$ $\mathrm{B}_{-4}$ 付近によどみ点が発生し，よどみ点を境に前交通動 脈と枝管への流机に分かれる。合流管から枝管に至る 側壁のほうに主流が偏向し，速度こう配が大きくなり， 他方外壁では速度こう配が隇少し $\mathrm{A}_{26}$ 付近で逆流が発 生している。

実験では，供試流路の真上に設置したヘッドタンク から左右対称な配管を通って隔たり，エルボを介して 対称な助走部（直管長さ $2.3 \mathrm{~m}$ ) を通って供試流路モデ

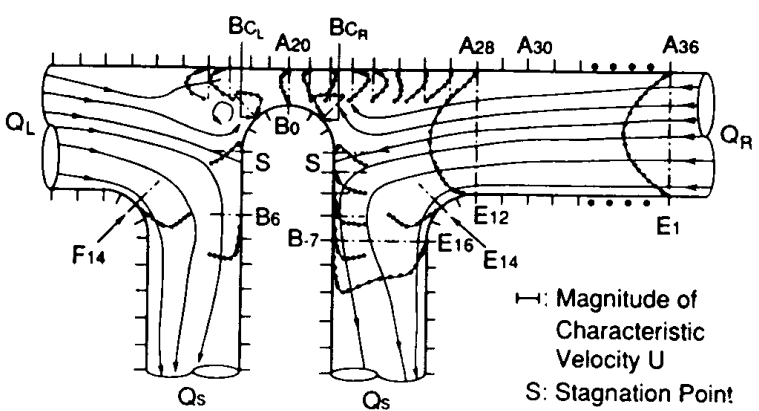

(a) Even flow ratio ( $\left.R e=400, Q_{R} / Q_{L}=1.0\right)$

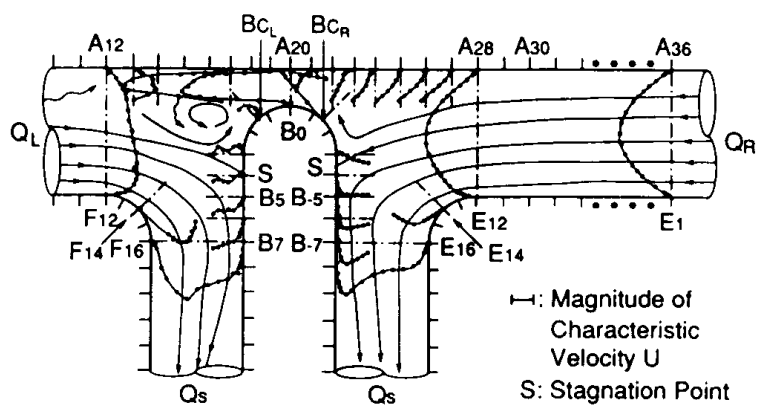

(b) Imbalance flow ratio $\left(R e=390, Q_{R} / Q_{L}=1.5\right)$

Fig. 6 Axial velocity profile at symmetrical plane

ルに合流する．断面 $\mathrm{A}_{20}-\mathrm{B}_{0}$ の前交通動脈部を通って， 右側の合流管から全流量の $1 \%$ 程度の左側に通過する 流れがあるため, 厳密な流量比は $Q_{R} / Q_{L}=1.02$ であ る.

不均衡流量比 $Q_{R} / Q_{L}=1.5 \sigma$ 場合 [図 6(b)]，右側 の外壁上では速度こう配は，前交通動脈部に近づく 急激に増加する. 右合流管から全流量の $10 \%$ 程度の流 体が前交通動脈を通り左合流管に噴流状に流入するた め，左側外壁上に大きな逆流が発生し，流れは不安定 となる，中間壁では，左右の合流管からの流れが衝突 するよどみ点 Sの位置恃等流量比の場合と大きな違 いはない。

流量比 $Q_{R} / Q_{L}=1.0$ および 1.5 ともに, 流れ分割部 である中間壁によどみ点が発生し，よどみ点から前交 通動脈への中間壁上で速度こう配は大きくなる，特に 不均衡流量比 $Q_{R} / Q_{L}=1.5$ の場合, 流量の多い右側の $\mathrm{B}_{C R}$ および $\mathrm{B}_{0}$ で極めて大きな速度こう配となる。

$3 \cdot 2$ 壁せん断応力分布 2 種類の流量比 $Q_{R} / Q_{L}$ $=1.0$ および 1.50 場合，対称面にある管壁上のせん 断応力分布を図 7 および図 8 に示す。各図の（a)およ び(b)は，それぞれ合流管および枝管の壁せん断応力 分布である. 各横軸は合流管半径 $R_{0}=D_{0} / 2$ で無次元 化してある.哷軸である壁せん断応力 $\tau_{W}$ は, 左右の合 


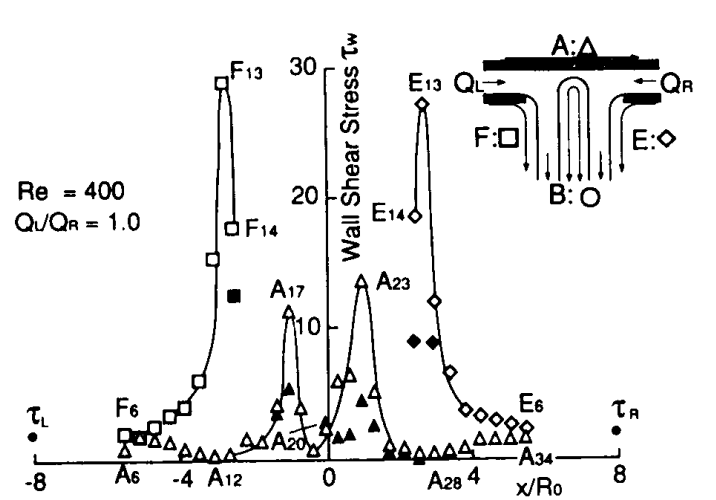

(a) Confluent tube

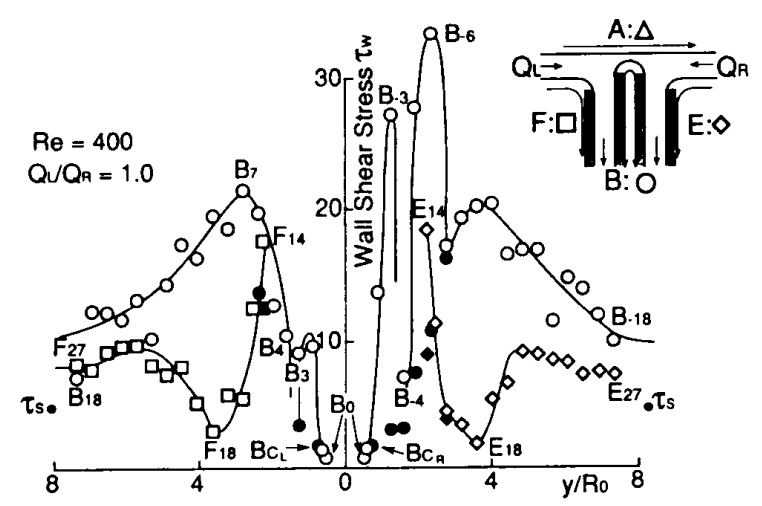

(b) Bifurcating tube

Fig. 7 Distribution of dimensionless wall shear stress in confluent and bifurcating channel at even flow ratio $\left(\operatorname{Re}=400, Q_{R} / Q_{L}=1.0\right)$

流管の平均流量に基づく合流管上流ポアスイユ流れで 2.0 として無次元化する. 図 7,8 中の Closed Symbol は LVD で測定した速度から算出した壁せん断応力で あり, Open Symbol は電気化学的方法による結果, 実 線は電気化学的方法の結果を結んだものである。なお， 電気化学的な測定法ではその作用方向を検知できない ため, 逆流が発生している場合のように壁せん断応力 が主流に対して逆向きで，負の值となっていると予想 される場合でも正の絶対值で示す.同様に，LDVで測 定した速度から算出した壁せん断応力を示す場合に も，十分上流の両合流管では主流の向きが反対であり， かつ合流点回りではその流れの変化が大きいことか ら，絶対値で示す.したがって，壁せん断応力の作用方 向を見るためには速度分布と対応させる必要がある。 なお，図 8 の記号を通る垂直線は，流れの不安定(乱 れにより発生した壁せん断応力の変動を示す.図 7,8 中の $\tau_{L} ＼tau_{R}$ はそれぞれ左右の合流管で十分上流， $\tau_{s}$ は 枝管の十分下流でのポアズイユ流れの壁せん断応力を 示す。

等流量比 $Q_{R} / Q_{L}=1.0$ の場合 (図 7), 主管外壁 (A： $\triangle)$ に治う壁せん断応力は合流点に近ゔくと左右対称

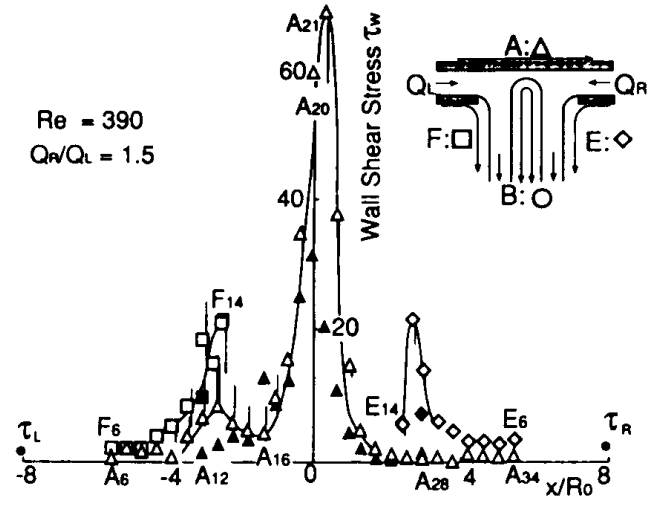

(a) Confluent tube

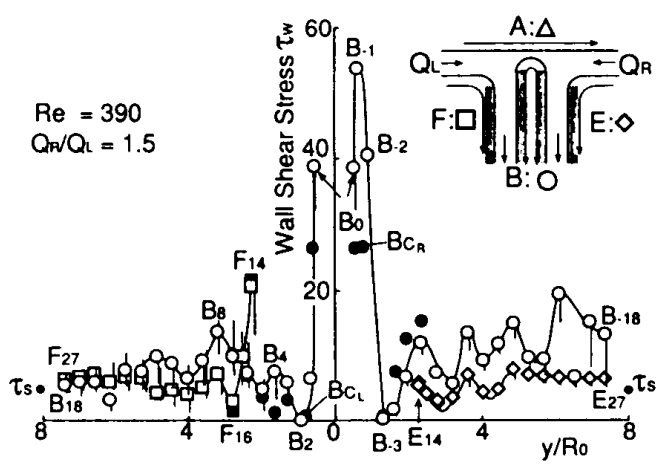

(b) Bifurcating tube

Fig. 8 Distribution of dimensionless wall shear stress in confluent and bifurcating channel at imbalance flow ratio $\left(\operatorname{Re}=390, Q_{R} / Q_{L}=1.5\right)$

に急激に增加し， $A_{17}, A_{23}$ で極大值を， $A_{19}$ で小さくな りその作用方向が反転する. 合流点の両側 $\mathrm{A}_{17}, \mathrm{~A}_{23}$ の 極大值は，外壁上に発生する左右対称な渦による。流 れの方向を考慮すると, $\mathrm{A}_{13}$ から $\mathrm{A}_{19}$ までの領域と $\mathrm{A}_{27}$ から上流の右合流管外壁では，壁せん断応力の作用 方向は $x$ 軸の負の方向に作用する．したがって，方向

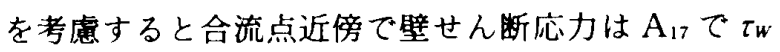
$=-11$ から， $\mathrm{A}_{23}$ で $\tau_{w}=13$ まで急激に変化する。枝管 に続く側壁 $(\mathrm{E}: \diamond, \mathrm{F}: \square)$ では主流が枝管側に偏向 するため, 曲面中央部 $\left(\mathrm{E}_{13}, \mathrm{~F}_{13}\right) \tau ゙ \tau_{w}=30$ の極大值に 達する，側壁上の壁せん断応力は枝管に入るといった ん隇少するが，その下流で增加に転じ $\tau_{s}$ に漸近する。 左右の側壁上ではほほ対称に分布している，流れを分 割している中間壁 $(\mathrm{B}: 0)$ 上では，流れ分割点である $\mathrm{B}_{0}$ で，上どみ点である $\mathrm{B}_{3}-\mathrm{B}_{4}$ および $\mathrm{B}_{-3}-\mathrm{B}_{-4}$ 付近で小 さな值をとる。このよどみ点近傍でその值は大きく変 動する。このように，流れ分割点近傍の中間壁拉よび 外壁で壁せん断応力は大きく変化し，かつ壁せん断応 力のこう配は非常に大きくなる。

不均衡流量比 $Q_{R} / Q_{L}=1.5$ の場合(図 8)，外壁 (A： $\triangle$ )に浻う壁せん断応力は合流点に近づくと急激に増 
加し， $A_{21}$ で $\tau_{W}=60$ 以上の大きな極大值， $A_{13}$ 付近で

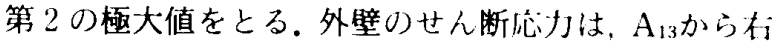
合流管全域にわたつて負の值となる，側壁 $(\mathrm{E}: 0$ 。 F：「?)ではほほ対称に分布しているが，合流部を通っ て流体が流入してくる流量の少ない方側の曲面壁中央 $\mathrm{F}_{14}$ の壁せん断忍力のほうが $\mathrm{E}_{14}$ よりも大きくなる。こ れは，前交通動脈部を通った流体が左合流管の主流を 側壁のほうに偏向させているためである，中間壁 $(\mathrm{B}$ ： りでは，左右の合流管から流れが衝突するよどみ点 $\mathrm{S}$ は $\mathrm{B}_{2}-\mathrm{B}_{3}$ ，および $\mathrm{B}_{-3}$ 付近に発生し等流量比の場命 と大きな相違はない，流量の多い灰側の $\mathrm{B}_{-1}$ で大きな 值 $\tau_{W}=50$, および合流点 $\mathrm{A}_{21}$ 近傍の極大值 $\tau_{W}=600$ ) 発生要因は，右合流管から全流量の $10 \%$ の流体が縮流 しながら前交通動脈部を通過する際の速度こう配の增 加による.さらに $\mathrm{A}_{13}$ の第 2 の極大值は，この縮流が噴 流となり左合流管外壁上に形成する旋[回流の最も速度 こう配の大きい位䈯である。命流管および枝管ともに， 前交通動脈部を通つて流体が流入してくる左側で流れ はより不安定となる。

電気化学的方法と速度分布から算出された壁せ几断 伈力は，壁せん断结力の絶対值が大きな位置で両者の

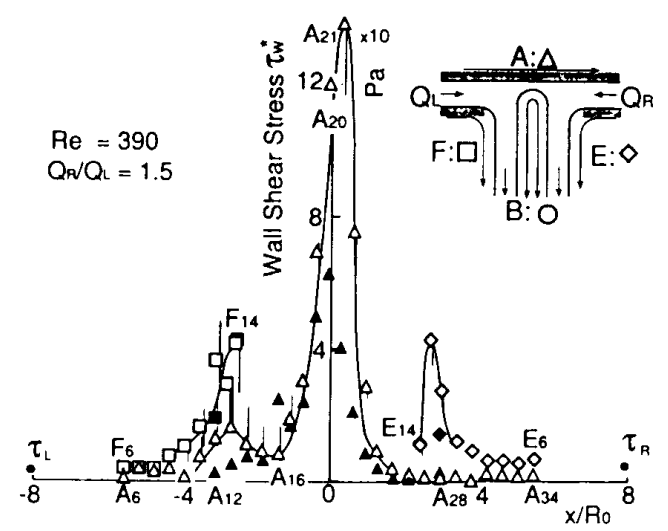

(a) Confluent tube

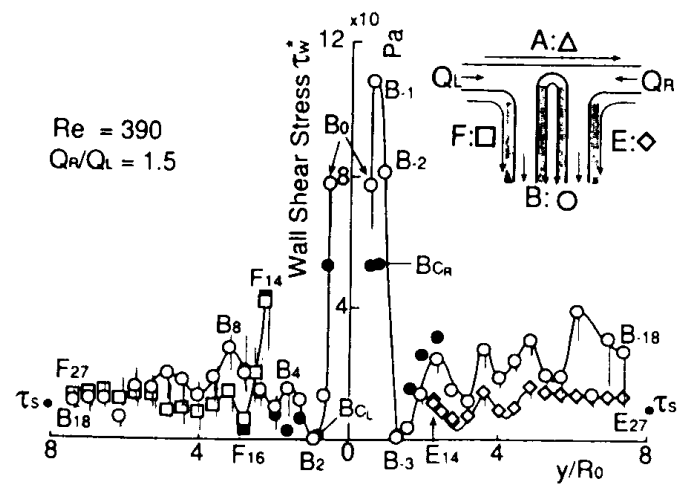

(b) Bifurcating tube

Fig. 9 Dimensional wall shear stress corresponding to Fig. 8 transformed by similarity $\left(R_{e}=390, Q_{R} / Q_{L}\right.$ $=1.5$ )
差が大きなる，電気化学的方法では，合流管上流て $R e=400$ に相当する直管ポアズイユ流れの壁せん断 忍力を 2.0 として無次元化した。図 7,8 に示すように， 流九分割点回りの)壁せん断応力は 30 (合流管上流值の 15 倍)以、旾の值に到達し，ポアズイユ流れで換算すれ ば刘誌する $R e$ 数は 6000 (15 倍)以上となる。この值 は凰流域での結果から外挿して算出したものであり， LDVによる速度行布から評価した結果が正しいとす れば，層流域以上の高 $R e$ 数の流れで壁せん断応力は 過大に評価されることになる。しかしながら，電気化 学的方法は流れ場金体にわたって連続して測定でき， 領域全体を把握する場合に極めて有効な方法である。

$3 \cdot 3$ 壁せん断応力变功の生理学的意茷不均衡 流量比 $Q_{R} / Q_{L}=1.50$ 場合, 実際の血管に対忍させて 相似則により換算した有次元壁せん断忍力 $\tau_{w}^{*}$ を，図 9 ( a )，（b）に亦吉。ただし，前交通動脈部上流の合流 管である前大脳動脈の内径は $3 \mathrm{~mm}^{(18)}$ ，血液粘度は純 水の 4 倍程度(3) とした。一般に，曲がり部や分岐，合 流などの影響を受けない動脈内の平均的な壁せん断纫 力は 1 ないし2 Pa とされているが(19), 合流管の十分

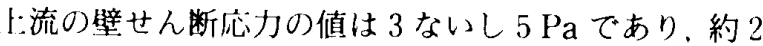
倍の大きさである。森竹(10)らによれば前交通動脈の動 脈りゅうは，合流管外壁よりも流れを分割する中間壁 :の流れが衝突するよどみ点近傍，かつ流量の多いほ うの壁上に発生するとされている。さらに，血管によ り病理学的異変の発生様式に差異はあるものの, 血管 内皮緇胞は集せん断応力が $39 \mathrm{~Pa}$ 以上になると才学的 に損傷を受けるとされている(5).そこで，中間壁で流 量の多いほうのよどみ点近傍に着目すれば B-1で惜 $=100 \mathrm{~Pa}$ となり，血管内皮細胞が損傷を受けるとされ る臨界値の 2 倍以上に達する。また，動脈内の平均的

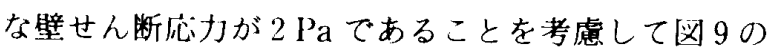
値の $1 / 2$ に換算したとしても，上どみ点近傍の $\mathrm{B}-1$ で $50 \mathrm{~Pa}$ となり臨界值に侻敵する。壁せん断応力の大き さは流路形状や合流流量比に依存すると考えられる が, 流量の多い幖間壁上に発生するという従来の病理 学的知見 ${ }^{(10)}$ と一致している。このように，前交通動脈 の流れ分割点近傍に発生する動脈りゅうの発生要因と して、流れが衝突する部位の回りで壁に作用する垂直 応力とともに接線力响に作用する壁せん断応力の大き さ，およびそのこう配が大きな影響をもつものと考え られる。

\section{4. 結 論}

本研究では, 刘向する二つの合流流れが合流後に直 角な同一方向の二つの流れに分岐する合流・分岐流路 
でモデル化した前交通動脈回りの基本的流れを実験的 に検討した。その結果, 動脈りゅうの好発部位である 前交通動脈回りで流れの変化が大きいことが示され た。

（1）動脈りゅうの好発部位である前交通動脈回り では，壁せん断応力の変化が大きい。特に，不均衡流量 比では，合流管外壁および流れを分割する中間壁上で 壁せん断応力は大きく変化する。

（2）動脈りゅうの好発部位とされている流量の多 いほうの中間壁上では，流れが衝乫するよどみ点と前 交通動脈部の間で壁せん断応力は急激に大きくなる。 この領域の壁せん断応力の増加はよどみ点から前交通 動脈に流入する縮流により生じる。

本研究費は平成 6 年度目本私学振興財団学術研究振 興資金によった，本研究の実験では元本学院生 津田 前去, 元本学学生 中鶴保久, 本学院生 岡部昭典の 各氏に扔手伝いいただいた。関係各位に謝意を表す。

\section{文}

(1) Lighthill, M. J., J. Fluid Mech., 52(1972), 475497.

(2) Roach, M. R.. ほ加2名, Stroke, 3(1972), 255-267.

(3) McIonald. D. A. Blood Flow in Arteries, 2 nd e'd., (1974), $92.9 \overline{5}$, Edward Arnolds.
(4) Caro, C. (c., 加2 多, Proc. R. Soc. London, Ser. B, 177 (1971), 109159

(5) Fry, D) L.. Circ. Res, 22(1968), 93108.

(6) Cornhill, J. F., ほ加2名. Atherosclerosis, 35(1980), 1013 110.

(7) Friedman, M. H., 活加 4 多, Atherosclerosis, 39(1981), 425436.

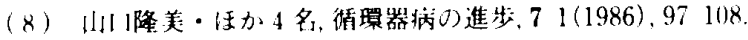

(9) Yamamoto, T., Zか 10 多. Arterios. Thromb., 12(1992), 626632 .

(10) 森竹洁兰・如5名, Neurologia Medico Chingica, 16 $5(1976), 427435$.

（11）大柣宏和・ほか 4 名，日本バイオレオロジ一学会論文集， 9 (1986), 335338 .

(12) Andrews. R. J. and Spiegel. P. K.. Surg. Neurol. 16 2(1981), 122 126.

(13) Kayembe, K. N. T., 活か 3 名, Stroke, 15 5(1984), 846 850.

(14) Ujiie, H., 仗か6 名, Stroke, 24 12(1993), 18501856.

(15) Hennerici, M.. ほか3 名, Surg. Neurol., 27(1987), 439 448.

(16) Mizushina. T., Adt. Heat Transt. 7(1971). 87161.

(17) Yamaguchi, R., Trans. ASME. J. Biomech. Eng.. 111 (1989). 4754

(18) Reutern, (. M. and Budingen, H. J., Vltrasound Diag nosis of Cerebrotascular Discase, (1993), 38.46. Thieme Medical Publishers.

(19) Giddens, D. P., W 2 2 名. Appl. Mech. Ret., 43 5. Part. 2(1990), 98102 